\title{
Interregional cytogenetic comparisons in Halichoeres and Thalassoma wrasses (Labridae) of coastal and insular regions of the southwestern Atlantic
}

\author{
K.D.J. Amorim ${ }^{1}$, M.B. Cioffi ${ }^{2}$, L.A.C. Bertollo ${ }^{2}$, R.X. Soares ${ }^{1}$, L.L. Calado ${ }^{1}$, \\ A.T. Borges ${ }^{1}$, G.W.W.F. Costa $^{1}$ and W.F. Molina ${ }^{1}$ \\ ${ }^{1}$ Departamento de Biologia Celular e Genética, Centro de Biociências, \\ Universidade Federal do Rio Grande do Norte, Natal, RN, Brasil \\ ${ }^{2}$ Departamento de Genética e Evolução, Universidade Federal de São Carlos, \\ São Carlos, SP, Brasil \\ Corresponding author: W.F. Molina \\ E-mail: molinawf@yahoo.com.br \\ Genet. Mol. Res. 16 (2): gmr16029650 \\ Received February 17, 2017 \\ Accepted March 23, 2017 \\ Published May 10, 2017 \\ DOI http://dx.doi.org/10.4238/gmr16029650
}

Copyright (C) 2017 The Authors. This is an open-access article distributed under the terms of the Creative Commons Attribution ShareAlike (CC BY-SA) 4.0 License.

\begin{abstract}
The distribution patterns of marine biodiversity are complex, resulting from vicariant events and species dispersion, as well as local ecological and adaptive conditions. Furthermore, the wide geographic distribution of some species may be hindered by biogeographical barriers that can interfere in the gene flow. Cytogenetic analyses in marine fishes, especially those involving populations in small remote insular environments, remain scarce. In the Western Atlantic, species of wrasses from the genera Halichoeres and Thalassoma occur in biogeographic arrangements that make it possible to analyze cytogenetic patterns between coastal and widely separated island populations. Species of these genera were punctually analyzed in some Atlantic regions. In this study, we compared several chromosomal features, such as karyotype macrostructure, heterochromatic patterns,
\end{abstract}

Genetics and Molecular Research 16 (2): gmr16029650 
patterns of base-specific fluorochromes, Ag-NORs, and $18 \mathrm{~S}$ and $5 \mathrm{~S}$ ribosomal sites in Thalassoma noronhanum, Halichoeres poeyi, and Halichoeres radiatus individuals from distinct coastal or insular regions of Atlantic. Notably, all of them are characterized by multiple $18 \mathrm{~S}$ and 5S rDNA sites with syntenic arrangements in some chromosome pairs. Individuals of T. noronhanum (between the insular regions of Rocas Atoll and Fernando de Noronha Archipelago - FNA) and H. poeyi (coastal areas from Northeastern Brazil) show no detectable differences among their cytogenetic patterns. On the other hand, $H$. radiatus from FNA and São Pedro and São Paulo Archipelago exhibit differences in the frequency of rDNA sites that could suggest some level of population structuring between these insular regions. Interregional cytogenetic inventories of marine species with wide geographic distribution need to be rapidly expanded. These data will allow a better understanding of the level of chromosomal stability between vast oceanic spaces, which may be less than previously thought.

Key words: Atlantic Labridae species; Population cytogenetics; rDNA; Gene synteny; Chromosome variability

\section{INTRODUCTION}

In the Western Atlantic, physical and ecological conditions may differ within large ocean expanses occupied by a number of fish species (Ferreira et al., 2004; Floeter et al., 2007). These variations delimit conspicuously distinct regions inside the geographic occupation setting of species stimulating analyses of the degree of genetic connectivity. In contrast to the freshwater fauna, where conspicuous barriers provide ample opportunities for allopatric speciation, oceans contain fewer geographic barriers (Rocha et al., 2007). Furthermore, species exhibit high potential larval dispersion, which under physical and ecological conditions may interfere in the fixation of exclusive chromosomal rearrangements (Molina and Galetti, 2004; Molina, 2007; Sena and Molina, 2007). Vicariant events such as the closure of the Panama Isthmus, the Amazon River discharge and the intrinsic capacities of dispersion and adaptation to new habitats, regulate marine biodiversity in the tropical Atlantic (Rocha, 2003; Floeter et al., 2007). In fact, physical agents, such as marine currents, temperature and salinity, contribute to different levels of gene flow among regions, even between congeneric species (Rocha and Bowen, 2008), and the joint actions of these parameters may shape chromosomal diversity among species. In this respect, genetic and cytogenetic analyses have significantly contributed to identify population variations in the marine environment. In fact, in this habitat, the biodiversity distribution patterns are complex as a result of the synergic interaction between vicariant events, species diversity, local adaptations, and ecological conditions (Rocha et al., 2005; Molina et al., 2012b).

Cytogenetic studies in marine fish populations have been largely improved by in situ hybridization techniques (Accioly et al., 2012; Artoni et al., 2015). Indeed, the distribution and frequency of a large number of chromosomal markers have allowed the discrimination of cryptic karyotypes or slight interspecific chromosomal differentiations, not diagnosed by conventional cytogenetic techniques (Motta-Neto et al., 2011; Lima-Filho et al., 2012).

Genetics and Molecular Research 16 (2): gmr16029650 
Phylogenetic analyses of Atlantic marine fishes have confirmed the action of biogeographic barriers, especially the Amazon discharge, in the restriction of gene flow among populations, culminating in speciation processes (Rocha, 2003). However, in addition to the large biogeographic barriers, other less discernible ones, and still little known in the Atlantic environment, can also promote genetic divergences among populations (da Cunha et al., 2014).

The Labridae family, with significant ecological dominance in reef systems (Westneat and Alfaro, 2005), displays examples of allopatric and ecological diversification (Rocha et al., 2005). In this sense, cytogenetic analyses of Labridae species/populations, some of them geographically distributed in remote areas and subjected to diverse environmental conditions, are useful tools to identify genetic structuring.

Halichoeres is the most representative Labridae genus, consisting of 80 species (Eschmeyer and Fong, 2016). Of these, 15 are found in the Atlantic environment, living in coastal regions and oceanic islands (Rocha et al., 2010). The genus Thalassoma, although distributed over all the oceans, is less diversified encompassing 28 species. Six of these species are found in the Western Atlantic (Froese and Pauly, 2016), of which T. noronhanum is widely distributed among Brazilian oceanic islands and coastal regions (Bernardi et al., 2004).

Given their vast geographic distribution, Halichoeres and Thalassoma species are particularly well suited for cytogenetic investigations considering their insular and coastal distribution in the Western Atlantic. Therefore, with the aim of comparing cytogenetic regional profiles, chromosomal features of $T$. noronhanum, $H$. poeyi, and $H$. radiatus were investigated from different spatial distribution (insular/insular; coastal/coastal), using conventional staining, C-banding, Ag-NORs, and fluorescence in situ hybridization (FISH) with $18 \mathrm{~S}$ and $5 \mathrm{~S}$ rDNAs probes.

\section{MATERIAL AND METHODS}

\section{Obtaining species and chromosomal preparations}

Specimens of three Labridae species were obtained from geographically separated regions in coastal and insular environments of the Western Atlantic. The Halichoeres poeyi (Steindachner, 1867) (Blackear wrasse) specimens were obtained in Extremoz $(\mathrm{N}=13$ ) $\left(5^{\circ} 42^{\prime} 20^{\prime \prime S}, 35^{\circ} 11^{\prime} 38^{\prime \prime} \mathrm{W}\right)$, on the coast of Rio Grande do Norte State, and on the coast of Salvador City $(\mathrm{N}=3)\left(13^{\circ} 00^{\prime} 40^{\prime \prime} \mathrm{S}, 38^{\circ} 30^{\prime} 35^{\prime \prime} \mathrm{W}\right)$ in Bahia State, both regions located on the northeast coast of Brazil and about $1000 \mathrm{~km}$ apart. Halichoeres radiatus (Linnaeus, 1758) (Puddingwife wrasse) individuals were from São Pedro and São Paulo Archipelago (SPSPA) $(\mathrm{N}=16)\left(00^{\circ} 55^{\prime} 02^{\prime \prime} \mathrm{N}\right.$,

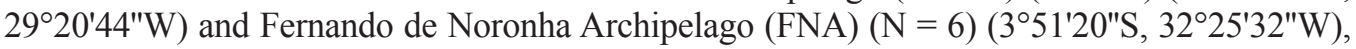
1100 and $367 \mathrm{~km}$, respectively, from the Brazilian mainland. Cytogenetic analyses of Thalassoma noronhanum (Boulenger, 1890) (Noronha wrasse) were conducted in individuals from FNA (N $=15)\left(3^{\circ} 51^{\prime} 20^{\prime \prime} \mathrm{S}, 32^{\circ} 25^{\prime} 32^{\prime \prime} \mathrm{W}\right)$ and Rocas Atoll $(\mathrm{RA})(\mathrm{N}=22)\left(3^{\circ} 51^{\prime} 59^{\prime \prime} \mathrm{S}, 33^{\circ} 48^{\prime} 20^{\prime \prime} \mathrm{W}\right), 150 \mathrm{~km}$ apart and the latter $267 \mathrm{~km}$ from the mainland (Figure 1).

The specimens were submitted to mitotic stimulation using intraperitoneal inoculation of fungal and bacterial antigen complexes (Molina et al., 2010). The collection and handling of specimens followed protocols approved by the Ethics Committee on the Use of Animals of the Federal University of Rio Grande do Norte (Process No. 044/2015). Mitotic chromosomes were obtained from the suspension of kidney fragments, according to the in vitro technique (Gold et al., 1990). The chromosomes were stained with 5\% Giemsa solution and diluted in 
phosphate buffer, $\mathrm{pH}$ 6.8. The heterochromatic regions were visualized using the C-banding technique (Sumner, 1972), while the nuclear organizing regions (Ag-NORs) were identified by the silver nitrate impregnation method (Howell and Black, 1980). Staining with fluorochromes mithramycin (MM) and 4',6-diamidino-2-phenylindole (DAPI) followed the protocol of Schweizer (1976).

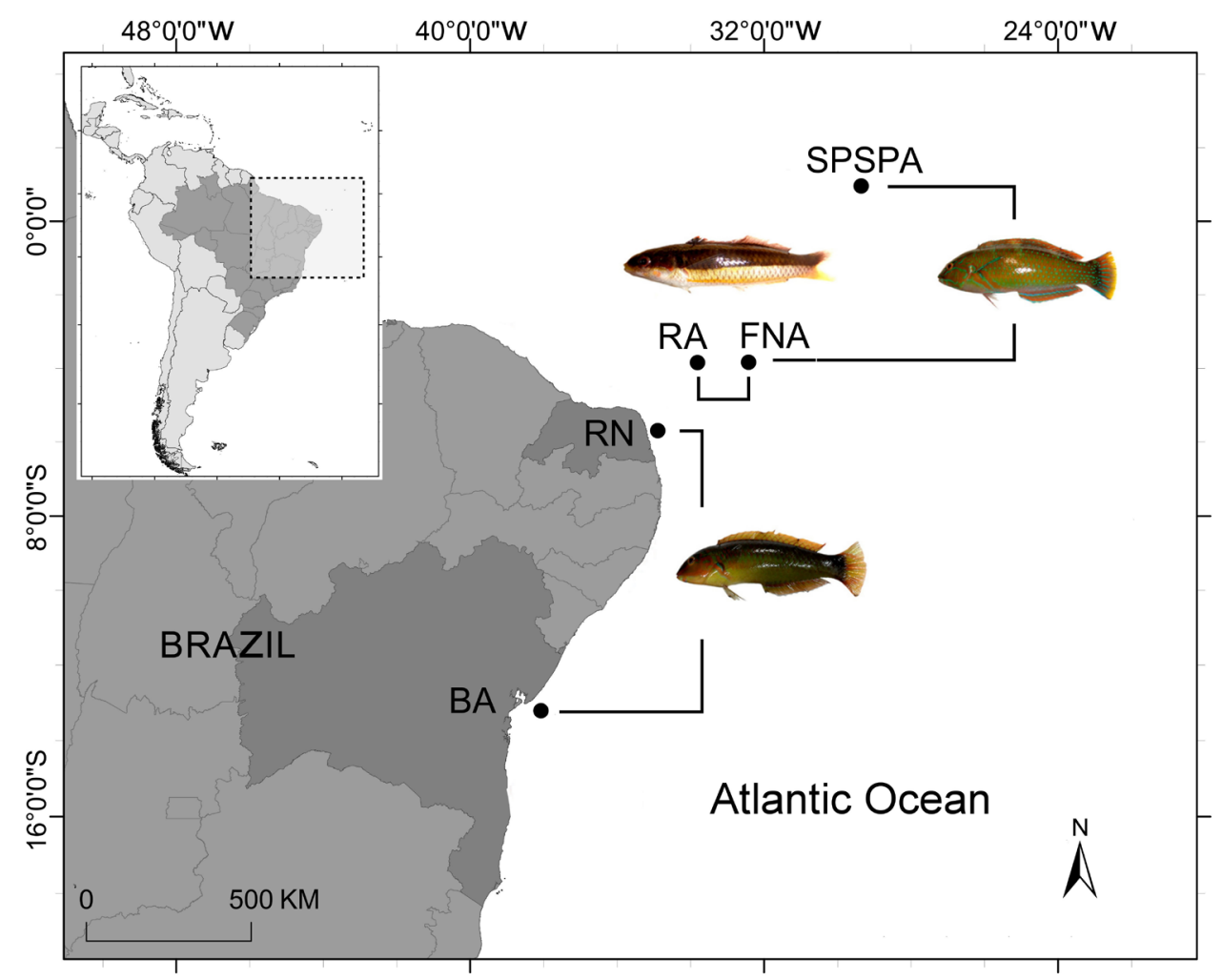

Figure 1. Collection points of Thalassoma noronhanum [Rocas Atoll - (RA) and Fernando de Noronha Archipelago (FNA)], Halichoeres radiatus [São Pedro and São Paulo Archipelago (SPSPA) and - FNA] and Halichoeres poeyi [Rio Grande do Norte $(\mathrm{RN})$ and Bahia (BA) coastal regions] in the Western Atlantic.

\section{Obtaining probes for chromosomal hybridization}

The 5S and 18S rDNA probes, containing approximately 200 and $1400 \mathrm{bp}$, respectively, were obtained by polymerase chain reaction (PCR) from the nuclear DNA of Rachycentron canadum (Teleostei, Perciformes), using primers A 5'-TAC GCC CGA TCT CGT CCG ATC-3' and B 5'-CAG GCT GGT ATG GCC GTA AGC-3' for 5S rDNA (Pendas et al., 1994), and NS1 5'-GTA GTC ATA TGC TTG TCT C-3' and NS8 5'-TCC GGT GCA TCA CCT ACG GA-3' for 18S rDNA (White et al., 1990). The 18S and 5S rDNA probes were labeled with digoxigenin11-dUTP and biotin-11-dATP (Invitrogen, Carlsbad, CA, USA), respectively, according to manufacturer's instructions. 


\section{Chromosomal hybridization}

FISH was performed according to Pinkel et al. (1986). Metaphase chromosomes were treated with RNAse $(20 \mu \mathrm{g} / \mathrm{mL}$ in $2 \mathrm{X} \mathrm{SSC})$ at $37^{\circ} \mathrm{C}$ for $1 \mathrm{~h}$, and pepsin $(0.005 \%$ in $10 \mathrm{mM}$ $\mathrm{HCl}$ ) for $10 \mathrm{~min}$, fixed with $1 \%$ formaldehyde for $10 \mathrm{~min}$ and then dehydrated in an alcohol series $(70,85$, and $100 \%)$ for $5 \mathrm{~min}$ in each step. The slides with metaphase chromosomes were incubated in $70 \%$ formamide $/ 2 \mathrm{X} \mathrm{SSC}$ at $72^{\circ} \mathrm{C}$, for $5 \mathrm{~min}$ and dehydrated again in an alcohol series (70, 85, and $100 \%)$ for $5 \mathrm{~min}$ in each step. The hybridization solution, consisting of $50 \%$ formamide, $2 \mathrm{X} \mathrm{SSC}, 10 \%$ dextran sulfate and the denatured probe $(5 \mathrm{ng} / \mu \mathrm{L})$, in a final volume of $30 \mu \mathrm{L}$, was deposited onto the slide and hybridization was performed for $16 \mathrm{~h}$ at $37^{\circ} \mathrm{C}$. Post-hybridization washes were conducted in $15 \%$ formamide $/ 0.2 \mathrm{X} \mathrm{SSC}$ at $42^{\circ} \mathrm{C}$, for $20 \mathrm{~min}$, followed by washing in $0.1 \mathrm{X} \mathrm{SSC}$ at $60^{\circ} \mathrm{C}$ for $15 \mathrm{~min}$ and $0.5 \%$ Tween $20 / 4 \mathrm{X} \mathrm{SSC}$ for $5 \mathrm{~min}$ at $25^{\circ} \mathrm{C}$. The slides were then incubated for $15 \mathrm{~min}$ in a $5 \% \mathrm{NFDM} / 4 \mathrm{X}$ SSC blocking buffer and washed in $0.5 \%$ Tween $20 / 4 \mathrm{X}$ SSC for $15 \mathrm{~min}$. The hybridization signals of the probes were detected using anti-digoxigenin conjugated with rhodamine (Roche, Mannheim, Germany) for the 18S rDNA probe and streptavidin-FITC (Vector, Burlingame, USA) for the $5 \mathrm{~S}$ rDNA probe. The chromosomes were counterstained with Vectashield/DAPI $(1.5 \mu \mathrm{g} /$ $\mathrm{mL}$ ) (Vector). The metaphases were photographed with an Olympus ${ }^{\mathrm{TM}}$ BX50 epifluorescence microscope, coupled to an Olympus DP73 digital capture system, using the cellSens software (Olympus Corporation, Ishikawa, Japan). The chromosomes were defined based on the ratio between the arms, according to Levan et al. (1964).

\section{RESULTS}

The cytogenetical data extended and consolidated the previous information available for these species (Sena and Molina, 2007; Amorim et al., 2016; Almeida et al., 2017). In fact, the three species present karyotypes with $2 n=48$ chromosomes in the marine regions analyzed and a similar chromosomal macrostructure, with only some small differences for T. noronhanum. The heterochromatin is also preferentially located in centromeric and pericentromeric positions of the chromosomes in all species (Figures 2 and 3).

T. noronhanum (RA and FNA insular regions) has a karyotype composed of $2 \mathrm{sm}+46 \mathrm{a}$ (Figure 2). The Ag-NOR sites are located on the short arms of pair 1, the only submetacentric pair of the karyotype (Figure 2a). The 18S rDNA sites are present in the same region of this chromosome pair, and co-localized with 5S rDNA. Moreover, 5S rDNA sites also occupy the short arms of pair 14 (Figure $2 \mathrm{~g}$ ). The $\mathrm{MM}^{+}$regions are co-located with the rDNA sites, except in pair 5 (Figure 2e).

$H$. poeyi (coast of RN and BA) and $H$. radiatus (FNA and SPSPA) exhibit karyotypes consisting entirely of acrocentric chromosomes (Figures 2 and 3). The first species exhibits multiple Ag-NOR sites located on the short arm of pairs 5 and 15 (Figure 2). The mapping of rDNA sequences identified multiple $18 \mathrm{~S}$ sites occupying the short arms of pairs 5, 6, and 15 (Figure $2 \mathrm{~h}$ ), and $18 \mathrm{~S} / 5 \mathrm{~S}$ arrays on chromosome pairs 5 and 15 . The samples of $T$. noronhanum and $H$. poeyi, despite exhibiting diversified location and organization of ribosomal sites, show similar interregional patterns.

By contrast, $H$. radiatus showed chromosomal differentiations for individuals from the FNA and SPSPA islands. In this species, two Ag-NOR bearing chromosome pairs (pairs 5 and 24) occur in FNA individuals, while three Ag-NOR bearing chromosome pairs (pairs 5,

Genetics and Molecular Research 16 (2): gmr16029650 
14, and 24) are present in the SPSPA individuals (Figure 3). However, hybridization with $18 \mathrm{~S}$ rDNA probe also indicated additional signals in pair 15 for both FNA and SPSPA individuals, corresponding thus to three and four NOR bearing chromosome pairs, respectively. With respect to the ribosomal sequence organization, the $18 \mathrm{~S}$ rDNA sites are located exclusively in pair 15 in individuals of both insular regions. In addition, $18 \mathrm{~S} / 5 \mathrm{~S}$ co-located arrays occur in pairs 5 and 24 from both localities and in pair 14 from SPSPA individuals (Figure $3 \mathrm{~g}$ and h). Although some intra-regional polymorphism was detected for 18S rDNA sites, the modal frequency differs significantly between the geographical regions and can be used as a conspicuous cytogenetic marker between the FNA and SPSPA of $H$. radiatus individuals.

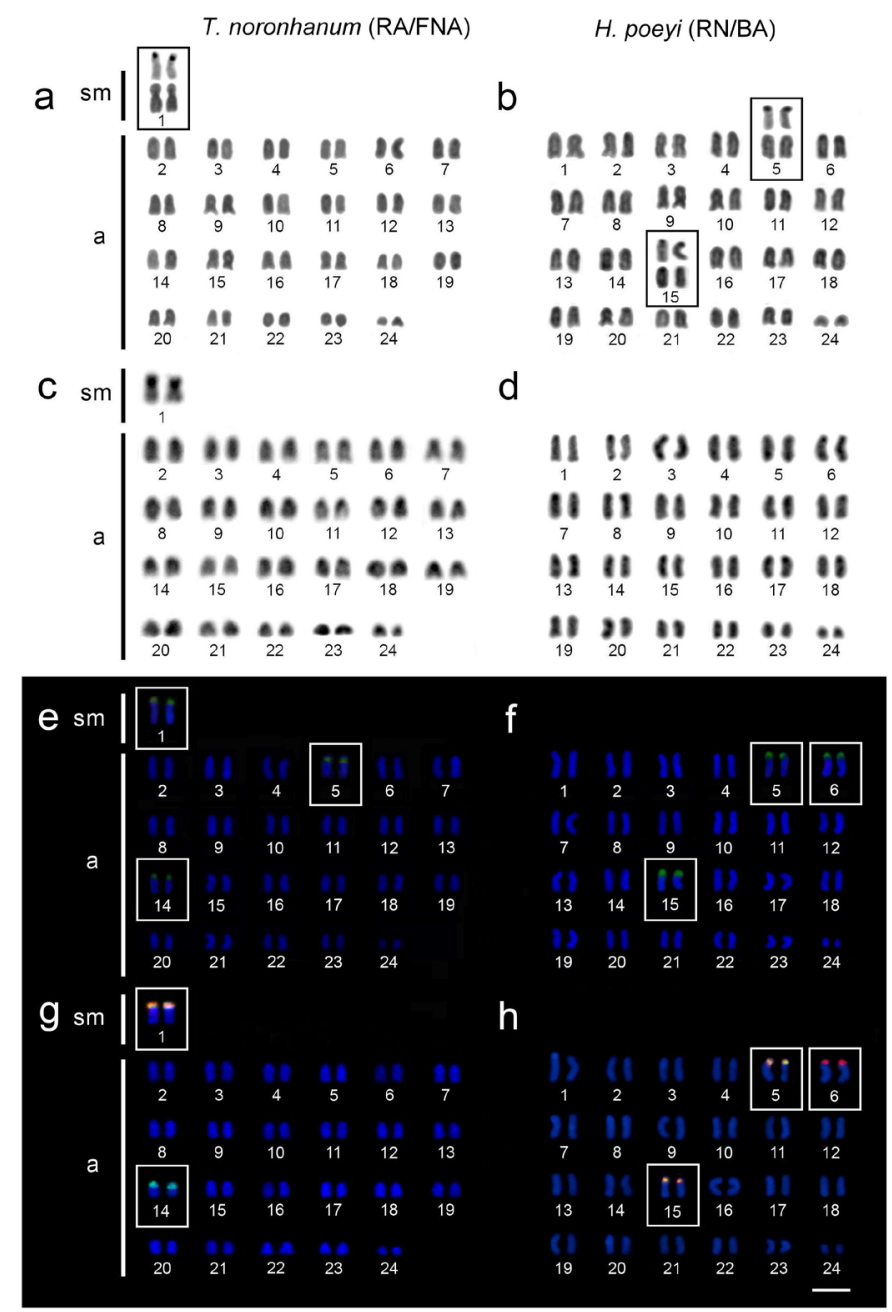

Figure 2. Karyotypes of Thalassoma noronhanum and Halichoeres poeyi. Giemsa staining (a and b), C-banding (c and d), MM/DAPI (e and f), and FISH with 18S (red) and 5S (green) rDNA probes (g and $\mathbf{h})$. The boxes highlight rDNA-bearing chromosome pairs. RA - Rocas Atoll; FNA - Fernando de Noronha Archipelago; BA - Bahia State; RN - Rio Grande do Norte State. Bar $=5 \mathrm{~mm}$. 
H. radiatus (FNA)

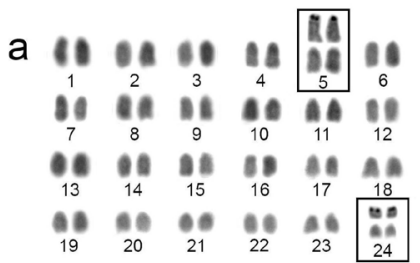

C I

$\begin{array}{llllll}\text { 11 } & 11 & 11 & 11 & 11 & 11 \\ 1 & 2 & 3 & 4 & 5 & 6 \\ 11 & 11 & 11 & 11 & 11 & 11 \\ 7 & 8 & 9 & 10 & 11 & 12 \\ 11 & 11 & 11 & 11 & 11 & 11 \\ 13 & 14 & 15 & 16 & 17 & 18 \\ 11 & 11 & 11 & 11 & 11 & 11 \\ 19 & 20 & 21 & 22 & 23 & 24\end{array}$

H. radiatus (SPSPA)

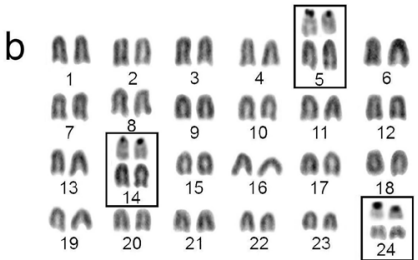

$\begin{array}{cccccc}\mathbf{1 1} & \mathbf{1 1} & \mathbf{1 1} & \mathbf{1 1} & \mathbf{1 1} & \mathbf{1 1} \\ 1 & 2 & 3 & 4 & 5 & 6 \\ \mathbf{1 1} & \mathbf{1 1} & \mathbf{1 1} & \mathbf{1 0} & \mathbf{1 1} & \mathbf{1 1} \\ 7 & 8 & 9 & 10 & 11 & 12 \\ 11 & 11 & 11 & \mathbf{1 1} & \mathbf{1 1} & \mathbf{1 1} \\ 13 & 14 & 15 & 16 & 17 & 18 \\ 11 & 10 & 11 & 11 & 10 & 18 \\ 19 & 20 & 21 & 22 & 23 & 24\end{array}$

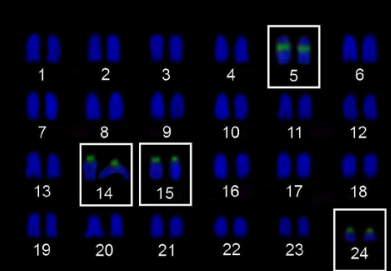

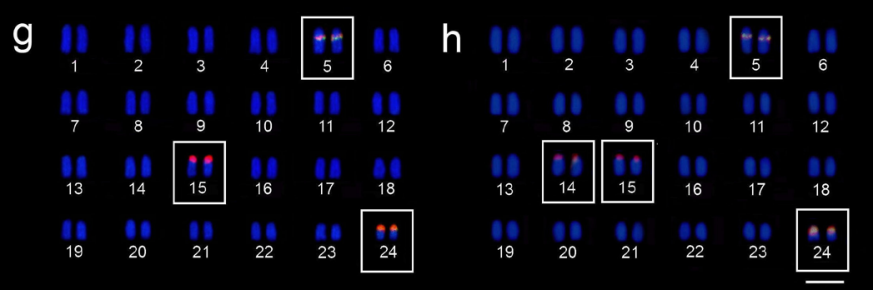

Figure 3. Comparative karyotype pattern of Halichoeres radiatus from Fernando de Noronha Archipelago (FNA) and São Pedro and São Paulo Archipelago (SPSPA). Conventional Giemsa staining (a and b), C-banding (c and d), MM/DAPI staining (e and f), and FISH using 18S (red) and 5S (green) rDNA probes ( $\mathbf{g}$ and $\mathbf{h}$ ). The boxes highlight the rDNA regions in the chromosomes. Bar $=5 \mathrm{~mm}$.

The organization of ribosomal sequences in the genome of the species analyzed exhibits structural peculiarities that are phylogenetically shared among Julidini species. Thus, all the species displayed $18 \mathrm{~S} / 5 \mathrm{~S}$ rDNA co-localized arrays, with some exclusive $18 \mathrm{~S}$ rDNA and 5S rDNA sites.

\section{DISCUSSION}

Are chromosome markers sufficiently sensitive to identify regional structuring in marine fishes? Comparative cytogenetic analyses between geographic samples of $T$. noronhanum (island-island), H. poeyi (coast-coast) and H. radiatus (island-island) are a first systematic assessment on the use of chromosome markers in identifying interpopulational 
variation in marine reef fishes. The delimitation of populations in the marine environments is largely dependent on indirect evidence and, in this respect, genetic and cytogenetic markers are very informative (Galetti et al., 2006; Artoni et al., 2015).

Labridae is one of the Perciformes groups with considerable chromosomal diversification. Their diploid numbers vary from 22 to 48 chromosomes, with a wide diversity of karyotype formulas (Sena and Molina, 2007; Arai, 2011). In this context, T. noronhanum, $H$. poeyi, and $H$. radiatus are among the species pool with structurally conserved karyotypes, with $2 n=48$ chromosomes exclusively or predominantly acrocentric. In fact, this is a frequent basal condition in several groups of Perciformes (Brum and Galetti, 1997; Galetti et al., 2006).

Among Labridae fish, complex heterochromatic regions have been identified in species from the Tribe Hypsigenyini, namely the hogfishes. The species Bodianus rufus, $B$. pulchellus, and $B$. insularis exhibit an atypical chromosomal region, exceptionally decondensed and argentophilic, but without affinity with $18 \mathrm{~S}$ rDNA probes and not a GC-rich region (Molina et al., 2012a). On the contrary, in the species now analyzed, the heterochromatin has a predominantly centromeric distribution, seemingly little variable, with low intra- and interspecific discriminatory power. However, base-specific fluorochromes exhibit multiple $\mathrm{GC}^{+}$heterochromatic regions (6 to 8 sites), congruent with Ag-NOR and 18S and 5S rDNA sites. This condition indicates heterogeneity in the heterochromatic distribution, as well as in the organization of the rDNA sites on the chromosomes.

Repetitive DNAs play an important role in the evolution of fish karyotype (Canapa et al., 2002; Cioffi et al., 2015). Indeed, because of their dynamics, they are associated with karyotype rearrangements and diversification in many groups of Perciformes (Getlekha et al., 2016). The three species exhibit $18 \mathrm{~S} / 5 \mathrm{~S}$ rDNA syntenic arrays, also identified in other Halichoeres species (Amorim et al., 2016), which suggest a shared condition in the Tribe Julidini. The $18 \mathrm{~S}$ and $5 \mathrm{~S}$ rDNA arrays occur in one chromosome pair in T. noronhanum (pair 1), in two pairs in $H$. poeyi (pairs 5 and 15), and in three pairs in $H$. radiatus (pairs 5,14 , and 24). Both Halichoeres species share 18S/5S rDNA sites in different locations of pair 5. In $H$. poeyi, the $18 \mathrm{~S} / 5 \mathrm{~S}$ rDNA arrays occupy a terminal position of the acrocentric pair 5 , while in $H$. radiatus they are clearly located in an interstitial position on this chromosome. Assuming that these pairs are homeologous, it is possible to infer a clear paracentric inversion involving the ribosomal sites. These rearrangements are under-notified in fish chromosomes due to their problematic identification, and their occurrence has already been reported for only a few species.

In T. noronhanum, $5 \mathrm{~S}$ rDNA sites are individualized (pair 14) or co-located with $18 \mathrm{~S}$ rDNA sites (pair 1). In the two Halichoeres species, all the 5S rDNA sites exhibit a syntenic $18 \mathrm{~S} / 5 \mathrm{~S}$ arrangement. Syntenic arrangements of ribosomal genes are a derived condition in Perciformes (Nakajima et al., 2012; Calado et al., 2014; Costa et al., 2016) and Characiformes (Voltolin et al., 2013), and this exclusive feature in both Halichoeres species demonstrates that this organization does not interfere with the gene function. The similarity in the organization of ribosomal genes in the Thalassoma and Halichoeres genera indicates a symplesiomorphic condition in the Julidini species. Data from a broader taxonomic spectrum may probably explain whether this gene arrangement is more basal and shared with other Labridae groups.

Geographic comparative analyses in Noronha wrasse (T. noronhanum) demonstrate a same chromosome pattern between individuals from the oceanic islands of the RA and FNA, including the frequency and distribution of $18 \mathrm{~S}$ and $5 \mathrm{~S}$ rDNA sites. Similarly, H. poeyi showed no detectable chromosomal differences between the RN and BA coasts, where the

Genetics and Molecular Research 16 (2): gmr16029650 
Brazil Current flows from the former to the latter. On the other hand, earlier cytogenetic inter-regional studies suggest that this karyotypic similarity may not be sustained in $\mathrm{H}$. poeyi individuals from higher latitudes, such as those from the Rio de Janeiro (RJ) coast, located around $1400 \mathrm{~km}$ from South BA. In contrast to the specimens from RN and BA, which present two Ag-NOR bearing chromosome pairs, those from RJ have preferentially one chromosome pair (Sena and Molina, 2007), suggesting cytogenetic differentiations among them.

H. radiatus, despite exhibiting structurally similar karyotypes, differs in the frequency of the $18 \mathrm{~S}$ ribosomal sites among insular regions. In individuals from FNA, these sites are distributed into three chromosome pairs $(5,15$, and 24), while in the individuals from SPSPA, these sites also occur in pair 14. Accordingly, the distribution of the $\mathrm{GC}^{+}$regions is in agreement with the location of the ribosomal sites on the chromosomes.

Phylogeographic studies in Pomacentridae species from the same coastal and insular regions, surveyed in the present study, report similar data for molecular markers. Indeed, analyses of the mtDNAD-loop sequence in the Chromis multilineata from the ocean coast and the FNA and SPSPA regions, identified high genetic similarity between the FNA and the coast individuals, which includes the RA (da Cunha et al., 2014), a condition compatible with the chromosomal similarity exhibited by $T$. noronhanum. On the other hand, there is a moderate level of genetic structuring between the FNA and SPSPA populations, in line with the variation in the number of the $18 \mathrm{~S}$ ribosomal sites that occur in $H$. radiatus individuals between these oceanic islands.

The remote SPSPA is formed by a few rocky islands located in the Meso-Atlantic chain, $1100 \mathrm{~km}$ from the closest point on the Brazilian mainland. It is one of the few places where the ocean floor rises above the surface, representing an ecologically peculiar region, with high endemism and low diversity (Ferreira et al., 2009), when compared to other Brazilian oceanic islands. This archipelago is influenced by the South Equatorial Current in the East-West direction and the South Equatorial Countercurrent in the opposite direction. FNA is closer to the mainland $(365 \mathrm{~km})$ and $600 \mathrm{~km}$ apart from SPSPA. The FNA is influenced by both currents but, due to its proximity to the coast, is also under the effect of the North Brazil Current (Getlekha et al., 2016). The inter-regional variation, concerning the location and frequency of the ribosomal sites in $H$. radiatus, seems not to be only a polymorphic condition, but instead a response to some level of gene flow restriction between the insular areas. Indeed, the genetic individualization of species from the SPSPA (da Cunha et al., 2014) agrees with these data.

Phylogeographic analyses of the puddingwife wrasse (H. radiatus) in the Atlantic revealed no genetic differences between populations from FNA and St. Croix, an oceanic Caribbean island, despite the $4200 \mathrm{~km}$ separating these regions. Thus, vast geographic distances between populations of Halichoeres do not always restrict gene flow. However, in some species, it seems to be particularly affected by ecological differences among regions (Rocha et al., 2005). Vicariant events, combined with habitat differentiation (Bernardi et al., 2000), have been shown to be promoters of genetic diversification in some marine groups. In this respect, analysis based on the linear distances, especially among insular environments, may disregard physical and biological parameters that may act on regional chromosomal differentiations. On the other hand, the absence of chromosomal differentiations in $H$. poeyi individuals between the coastal regions of RN and BA corroborates the synergic action caused by the absence of physical barriers, ecological similarities, dispersive potential of the species, as well as the possible homogenizing action of the Brazil Current flowing southward between these regions.

Genetics and Molecular Research 16 (2): gmr16029650 
Intra-specific variations have been commonly analyzed from the standpoint of molecular markers. However, chromosomal investigation also constitutes a valuable tool for understanding the evolutionary dynamism and aspects of post-zygotic isolation among populations. In this sense, the increase of cytogeographic studies will improve the knowledge of the complex gene flow patterns, reproductive isolation and incipient speciation processes involving other fish species from the insular regions of the western South Atlantic.

\section{ACKNOWLEDGMENTS}

The authors thank CNPq (Conselho Nacional de Desenvolvimento Científico e Tecnológico) for financial assistance (Process \#442664/2015-0), IBAMA (Instituto Brasileiro do Meio Ambiente e dos Recursos Naturais Renováveis) for the license to collect specimens (Process \#19135/1), UFRN (Universidade Federal do Rio Grande do Norte) for providing the means to conduct the study, José Garcia Júnior for the taxonomic identification of the species, and Allyson S. Souza for creating the map.

\section{REFERENCES}

Accioly IV, Bertollo LAC, Costa GWWFC, Jacobina UP, et al. (2012). Chromosomal population structuring in carangids (Perciformes) between the north-eastern and south-eastern coasts of Brazil. Afr. J. Mar. Sci. 34: 383-389. http:// dx.doi.org/10.2989/1814232X.2012.689671

Almeida LA, Nunes LA, Bitencourt JA, Molina WF and Affonso PR (2017). Chromosomal evolution and cytotaxonomy in wrasses (Perciformes; Labridae). J. Hered. [Epub ahead of print].

Amorim KDJ, Cioffi MB, Bertollo LAC, Soares RX, et al. (2016). Co-located 18S/5S rDNA arrays: an ancient and unusual chromosomal trait in Julidini species (Labridae, Perciformes). Comp. Cytogenet. 10: 555-570. http://dx.doi. org/10.3897/compcytogen.v10i4.10227

Arai R (2011). Fish karyotypes: A check list. Springer, Tokyo.

Artoni RF, Castro JP, Jacobina UP, Lima-Filho PA, et al. (2015). Inferring diversity and evolution in fish by means of integrative molecular cytogenetics. Sci. World J. 2015: 365787. http://dx.doi.org/10.1155/2015/365787

Bernardi G, Robertson DR, Clifton KE and Azzurro E (2000). Molecular systematics, zoogeography, and evolutionary ecology of the atlantic parrotfish genus Sparisoma. Mol. Phylogenet. Evol. 15: 292-300. http://dx.doi.org/10.1006/ mpev.1999.0745

Bernardi G, Bucciarelli G, Costagliola D, Robertson DR, et al. (2004). Evolution of coral reef fish Thalassoma spp. (Labridae). 1. Molecular phylogeny and biogeography. Mar. Biol. 144: 369-375. http://dx.doi.org/10.1007/s00227003-1199-0

Brum MJI and Galetti PM, Jr. (1997). Teleostei ground plan karyotype. J. Comput. Biol. 2: 91-102.

Calado LL, Bertollo LAC, Cioffi MB, Costa GWFF, et al. (2014). Evolutionary dynamics of rDNA genes on chromosomes of the Eucinostomus fishes: cytotaxonomic and karyoevolutive implications. Genet. Mol. Res. 13: 9951-9959. http:// dx.doi.org/10.4238/2014.November.27.24

Canapa A, Cerioni PN, Barucca M, Olmo E, et al. (2002). A centromeric satellite DNA may be involved in heterochromatin compactness in gobiid fishes. Chromosome Res. 10: 297-304. http://dx.doi.org/10.1023/A:1016519708187

Cioffi MdeB, Bertollo LAC, Villa MA, de Oliveira EA, et al. (2015). Genomic organization of repetitive DNA elements and its implications for the chromosomal evolution of channid fishes (Actinopterygii, Perciformes). PLoS One 10: e0130199. http://dx.doi.org/10.1371/journal.pone.0130199

Costa GWWF, Cioffi MdeB, Bertollo LAC and Molina WF (2016). The Evolutionary Dynamics of Ribosomal Genes, Histone H3, and Transposable Rex Elements in the Genome of Atlantic Snappers. J. Hered. 107: 173-180. http:// dx.doi.org/10.1093/jhered/esv136

da Cunha IM, de Souza AS, Dias EA, Jr., Amorim KDJ, et al. (2014). Genetic multipartitions based on D-Loop sequences and chromosomal patterns in brown chromis, Chromis multilineata (Pomacentridae), in the Western Atlantic. BioMed Res. Int. 2014: 254698. http://dx.doi.org/10.1155/2014/254698

Eschmeyer WN and Fong JD (2016). Catalog of Fishes electronic version. Available at [http://researcharchive.calacademy.

Genetics and Molecular Research 16 (2): gmr16029650 
org/research/ichthyology/catalog/SpeciesByFamily.asp\#Labridae]. Accessed January 4, 2016.

Ferreira CEL, Floeter SR, Gasparini JL, Ferreira BP, et al. (2004). Trophic structure patterns of Brazilian reef fishes: A latitudinal comparison. J. Biogeogr. 31: 1093-1106. http://dx.doi.org/10.1111/j.1365-2699.2004.01044.x

Ferreira CEL, Luiz OJ, Feitoza BM, Ferreira CGW, et al. (2009). Peixes recifais: síntese do atual conhecimento. In: O Arquipélago de São Pedro e São Paulo: 10 Anos de Estação Científica. SECIRM, Brazil.

Floeter SR, Rocha LA, Robertson DR, Joyeux LC, et al. (2007). Atlantic reef fish biogeography and evolution. J. Biogeogr. 35: 22-47.

Froese R and Pauly D (2016). FishBase. World Wide Web electronic publication. Available at [www.fishbase.org]. Accessed June 15, 2016.

Galetti PM, Jr., Molina WF, Affonso PRAM and Aguilar CT (2006). Assessing genetic diversity of Brazilian reef fishes by chromosomal and DNA markers. Genetica 126: 161-177. http://dx.doi.org/10.1007/s10709-005-1446-Z

Getlekha N, Molina WF, de Bello Cioffi M, Yano CF, et al. (2016). Repetitive DNAs highlight the role of chromosomal fusions in the karyotype evolution of Dascyllus species (Pomacentridae, Perciformes). Genetica 144: 203-211. http:// dx.doi.org/10.1007/s10709-016-9890-5

Gold JR, Li YC, Shipley NS and Powers PK (1990). Improved methods for working with fish chromosomes with a review of metaphase chromosome banding. J. Fish Biol. 37: 563-575. http://dx.doi.org/10.1111/j.1095-8649.1990.tb05889.x

Howell WM and Black DA (1980). Controlled silver-staining of nucleolus organizer regions with a protective colloidal developer: a 1-step method. Experientia 36: 1014-1015. http://dx.doi.org/10.1007/BF01953855

Levan A, Fredga K and Sandberg A (1964). Nomenclature for centromeric position on chromosomes. Hereditas 52: 201220. http://dx.doi.org/10.1111/j.1601-5223.1964.tb01953.x

Lima-Filho PA, Cioffi MB, Bertollo LAC and Molina WF (2012). Chromosomal and morphological divergences in Atlantic populations of the frillfin goby Bathygobius soporator (Gobiidae, Perciformes). J. Exp. Mar. Biol. Ecol. 434-435: 63-70. http://dx.doi.org/10.1016/j.jembe.2012.08.004

Molina WF (2007). Chromosomal changes and stasis in marine fish groups. In: Fish cytogenetics (Pisano E, Ozouf-Costaz C, Foresti F and Kapoor BG, eds.). Science Publishers, Enfield, 69-110.

Molina WF and Galetti PM Jr (2004). Karyotypic changes associated to the dispersive potential on Pomacentridae (Pisces, Perciformes). J. Exp. Mar. Biol. Ecol. 309: 109-119. http://dx.doi.org/10.1016/j.jembe.2004.03.011

Molina WF, Alves DE, Araújo WC, Martinez PA, et al. (2010). Performance of human immunostimulating agents in the improvement of fish cytogenetic preparations. Genet. Mol. Res. 9: 1807-1814. http://dx.doi.org/10.4238/vol93gmr840

Molina WF, Costa GWWF, Cioffi MB and Bertollo LAC (2012a). Chromosomal differentiation and speciation in sisterspecies of Grammatidae (Perciformes) from the Western Atlantic. Helgol. Mar. Res. 66: 363-370. http://dx.doi. org/10.1007/s10152-011-0276-x

Molina WF, Motta Neto CC, Sena DCS, Cioffi MB, et al. (2012b). Karyoevolutionary aspects of Atlantic hogfishes (Labridae-Bodianinae), with evidence of an atypical decondensed argentophilic heterochromatin. Mar. Genomics 6: 25-31. http://dx.doi.org/10.1016/j.margen.2012.01.001

Motta-Neto CC, Cioffi MB, Bertollo LA and Molina WF (2011). Extensive chromosomal homologies and evidence of karyotypic stasis in Atlantic grunts of the genus Haemulon (Perciformes). J. Exp. Mar. Biol. Ecol. 401: 75-79. http:// dx.doi.org/10.1016/j.jembe.2011.02.044

Nakajima RT, Cabral-de-Mello DC, Valente GT, Venere PC, et al. (2012). Evolutionary dynamics of rRNA gene clusters in cichlid fish. BMC Evol. Biol. 12: 198. http://dx.doi.org/10.1186/1471-2148-12-198

Pendas AM, Moran P, Freije JP and Garcia-Vazquez E (1994). Chromosomal mapping and nucleotide sequence of two tandem repeats of Atlantic salmon 5S rDNA. Cytogenet. Cell Genet. 67: 31-36. http://dx.doi.org/10.1159/000133792

Pinkel D, Straume T and Gray JW (1986). Cytogenetic analysis using quantitative, high-sensitivity, fluorescence hybridization. Proc. Natl. Acad. Sci. USA 83: 2934-2938. http://dx.doi.org/10.1073/pnas.83.9.2934

Rocha LA (2003). Patterns of distribution and processes of speciation in Brazilian reef fishes. J. Biogeogr. 30: 1161-1171. http://dx.doi.org/10.1046/j.1365-2699.2003.00900.x

Rocha LA and Bowen BW (2008). Speciation in coral-reef fishes. J. Fish Biol. 72: 1101-1121. http://dx.doi.org/10.1111/ j.1095-8649.2007.01770.x

Rocha LA, Robertson DR, Roman J and Bowen BW (2005). Ecological speciation in tropical reef fishes. Proc. Biol. Sci. 272: 573-579. http://dx.doi.org/10.1098/2004.3005

Rocha LA, Craig MT and Bowen BW (2007). Phylogeography and the conservation of coral reef fishes. Coral Reefs 26: 501-512. http://dx.doi.org/10.1007/s00338-007-0261-7

Rocha LA, Pinheiro HT and Gasparini JL (2010). Description of Halichoeres rubrovirens, a new species of wrasse (Labridae: Perciformes) from the Trindade and Martin Vaz Island group, southeastern Brazil, with a preliminary

Genetics and Molecular Research 16 (2): gmr16029650 
mtDNA molecular phylogeny of new world Halichoeres. Zootaxa 2422: 22-30.

Schweizer D (1976). Reverse fluorescent chromosome banding with chromomycin and DAPI. Chromosoma 58: 307-324. http://dx.doi.org/10.1007/BF00292840

Sena DCS and Molina WF (2007). Chromosomal rearrangements associated with pelagic larval duration in Labridae (Perciformes). J. Exp. Mar. Biol. Ecol. 353: 203-210. http://dx.doi.org/10.1016/j.jembe.2007.08.020

Sumner AT (1972). A simple technique for demonstrating centromeric heterochromatin. Exp. Cell Res. 75: 304-306. http:// dx.doi.org/10.1016/0014-4827(72)90558-7

Voltolin TA, Penitente M, Mendonça BB, Senhorini JA, et al. (2013). Karyotypic conservatism in five species of Prochilodus (Characiformes, Prochilodontidae) disclosed by cytogenetic markers. Genet. Mol. Biol. 36: 347-352. http://dx.doi.org/10.1590/S1415-47572013000300008

Westneat MW and Alfaro ME (2005). Phylogenetic relationships and evolutionary history of the reef fish family Labridae. Mol. Phylogenet. Evol. 36: 370-390. http://dx.doi.org/10.1016/j.ympev.2005.02.001

White TJ, Bruns T, Lee S, Taylor JW, et al. (1990). Amplification and direct sequencing of fungal ribosomal RNA genes for phylogenetics. In: PCR Protocols: A guide to methods and applications (Innis M, Gelfand D, Sninsky J and White T, eds.). Academic Press Inc., Orlando.

Genetics and Molecular Research 16 (2): gmr16029650 